\title{
Functions of Fiction: Fighting Spouses around 1500
}

\author{
WIM BLOCKMANS \& TESS NEIJZEN
}

\begin{abstract}
Ten years ago Herman Pleij explored the 'enormous popularity' in Middle Dutch farces, parlour games, comedies and longer dramatic 1 poems of the theme of the henpecked husband ridiculed by his domineering, lazy, extravagant, malicious, often younger and eager wife. 'During the fifteenth century the theme continues to grow [...] undoubtedly reaching its climax in the first half of the sixteenth century'. 'Having drawn the necessary attention to typical literary techniques that present 'aspects of a selected and distorted reality' and the peculiar dynamism of literary traditions, Pleij suggests that 'the consciously caricatural portrayal of a domestic life turned upside down [seems] to indicate [...] a social hotbed. Or is it more a question of a navel-gazing literary game which challenges reality by referring to conjugal turmoil in nowhere-land? We eagerly await the historians' answer. ${ }^{2}$

Apparently the author had only to ask. In the past decade a source publication has appeared and a study of ecclesiastical jurisprudence in marital affairs in Brussels in the middle of the fifteenth century. ${ }^{3}$ Shortly
\end{abstract}

\footnotetext{
'The first author of the present contribution has written the whole text, using data from the master's dissertation by Tess Neijzen in the section 'Crimes within Marriage'. The second author acknowledged the final version of the paper.

${ }^{1} \mathrm{H}$. Pleij, 'Taakverdeling in het huwelijk. Over literatuur en sociale werkelijkheid in de late middeleeuwen', Literatuur 3 (1986) 66-76, in particular 68.

${ }^{2}$ Ibid., 69, 76.

${ }^{3}$ C. Vleeshouwers (ed.), Liber Sententicum van de Officialiteit van Brussel (Brussels 1983); M. Vleeshouwers-van Melkebesk, 'Aspects du lien matrimonial dans le Liber Sententiarum de Bruxelles (1448-1459)', Revue d'IIistoire du Droit (1985) 49-81.
} 
afterwards a number of other historical studies of marriage and society in the Low Countries during the late Middle Ages appeared but, alas, none of them responded to Pleij's urgent invitation to a dialogue. ${ }^{4}$ Yet the questions he raised are still very relevant. If it is true that a theme such as that of the domineering wife enjoys great success in diverse literary genres, then the question arises of why the public 'found the amusing arousal of public sentiment apparently useful and attractive because of its possibilities for making a connection to individual experiences, fantasies or even nightmares. ${ }^{5}$ It is essential to determine whether any convincing connection could be made and, if so, which. Pleij formulated the hypothesis that by about 1500 women had strengthened their position on the labour market to such an extent that men felt threatened. The literary representation of a man burdened by household chores under the thumb of his spendthrift, demanding, bossy wife would correspond to a model of an upside-down world. ${ }^{6}$

In his book on literature and urban culture Pleij has underpinned this argument with even more evidence from the visual arts and popular theology. The convergence of these very diverse media, which, in a way, reveal married life with more candour than ever before, makes his proposition all the more remarkable. ${ }^{7}$ Using Brussels as a focal point raises various questions as to which specifically local experiences could have, to a greater or lesser extent, contributed to the fact that, here of all places, the fictional theme of the bossy housewife should have attracted so much attention. The fact that five biblical and classical couples in a series of about fifty images in snow and ice allude to this, does not exactly make the subject prominent. As to the question of the farces, one might ask whether

\footnotetext{
${ }^{4} \mathrm{P}$ Bange \& A G Werler, 'De problematiek van het clandestıene huwelijk in het middeleeuwse bisdom Utrecht', in DE.H de Boer \& JW Marsilje (eds), De Nederlanden in de late middeleeuwen (Utrecht 1987) 393-409, W Preventer, 'Vrouwenrool als middel tot sociale mobiliteit in het 15e-eeuwse Zeeland', ibid, 410-24, B M de Meyer \& EW F van den Elzen, 'Het huwelyk van burgers in de late middeleeuwen', Tydschrift voor Soctale Geschiedents 14 (1988) 1-28, G M de Meyer, Min en onmin Mannen en vrouwen over hun samenleven aan het einde van de viffiende eeuw (Hilversum 1989), M Danneel, Weduwen en wezen in het laat-middeleeuwse Gent (Leuven/Apeldoorn 1995)

${ }^{5}$ Pleı, 'Taakverdeling', 69

${ }^{6}$ Ibid, 76

${ }^{7} \mathrm{H}$ Ple1j, De sneeuwpoppen van 1511 Literatuur en stadscultuur tussen middeleeuwen en moderne tud (Amsterdam/Leuven 1988) 9, 259-87
} 
these were written and performed around 1500 in Brussels more than anywhere else. This does not seem to be the case. It might have something to do with the availability, datability and locatability of our sources, but linking cultural phenomena to socio-economic circumstances is not an easy task.

In literary sociology the generally accepted principle is that the fictionconsuming public is attracted to a world other than that of its own reality. Tension is built up by the evocation of a more agreeable imaginary world, sometimes placed in a social environment higher than the intended audience, an exotic paradise, the Earthly Paradise or perhaps even Paradise itself. $^{8}$ This fictional technique plays up an ambition of social-climbing, fairly common throughout Western culture, which enhances the identification of the public with certain personages. Other fictional techniques are based on exaggeration, intensification or inversion of the real world. ${ }^{9}$ The function of humour in literary texts may well have been to enhance the acceptance of variation of the norms by presenting problematic situations in a positive light, or to demonstrate their necessity by showing the impossibility of any reversal of the roles. Examples of the former are to be found in the comic narratives with an erotic theme, of the latter in those concerning the sexual division of labour. ${ }^{10}$

It is clear that the farces to which Pleij refers are not situated in an idealized world. How do we know whether we are confronted with inversion or exaggeration of the real world of an audience of around 1500 ? Although it makes a considerable difference as far as interpretation is concerned, Pleij does not exclude this other possibility.

In this contribution we would like to test his hypothesis against nonfictional source material. In this way we hope to obtain a keener insight into the question of how fiction had to appear in relation to the reality of the public in order to be attractive. We hope thus to come closer to finding an answer to the question concerning the functions of fiction-consumption. Only when we are clear about the answer to this can we make use of fictional sources for a study of the actually-lived dimension of social relationships.

\footnotetext{
${ }^{8}$ H. Pleij, Dromen van Cocagne (Amsterdam 1997) 34-6, 468-72.

${ }^{9}$ H. Gaus, The Function of Fiction. The Function of Written Fiction in the Social Process (Ghent 1979) 128-33, 150-6.

${ }^{10}$ F.J. Lodder, Lachen om List en Lust. Studies over de Middelnederlandse komische versvertellingen (Ridderkerk 1996) 123-33.
} 


\section{Women in the Labour Market}

"Why then is the disruption of the order and division of tasks within marriage felt to be so threatening? The woman outside the home and in the labour market did not fit in with the progressive division of labour, institutionalization and democratization within the town walls " The explanation that is put forward here uses very broad concepts and therefore offers little to go on The concept of 'democratization' of the towns in the Netherlands in the late Middle Ages, first put forward by Henri Purenne in 1910, was finally laid to rest by Van Uytven in $1962{ }^{12}$ If there was a trend defining the political and governing atmosphere between about 1400 and 1550, then it was towards progressive yet intermittent oligarchization ${ }^{13}$ There is not enough clarification of the social effects that would be brought about by institutionalization, the second concept mentioned

The suggested inability of the 'woman outside the home' to fit in with the 'progressive division of labour' is more problematical Not necessarily all the alleged stories had an erotic or even urban underground In Anthonis de Roovere's Van den hennentaster the main issue is rather the division of labour between men and women in a peasant's household. ${ }^{14}$ Can we describe the alleged process of an increasing sexual division of labour exactly in its chronology, localization and effects on the position of the woman? Similar socio-economic processes were taking place in small regions while yet other trends prevalled elsewhere In those areas where the cloth industry was at its zenith in the thirteenth and fourteenth centuries, viz Flanders and Brabant, there were already signs of a far-reaching division of labour and specialization In those regions, at least, there was a tendency for the divisions of labour to decline in about 1500 The number of occupational groups registered in surveys made by the Bruges city

\footnotetext{
"Pleıy, 'Taakverdeling', 75

${ }^{12} \mathrm{R}$ van Uytven, 'Plutokratıe in de "oude demokratieen de Nederlanden", Handelıngen Koninklyke Maatschappty voor Taal en Letterkunde en Geschiedents 16 (1962) 373-409

${ }^{13}$ Just three recent studies as an example J P Sosson, Les Travaux Publtcs de la Ville de Bruges XIVe et XVe stecles Les materiaux Les Hommes (Brussel 1977) 155 201, W P Blockmans, 'Mobiliteit in stadsbesturen 1400-1550', in De Boer \& Marsilje (eds ), De Nederlanden, 236 60, M Boone, Gent en de Bourgondische hertogen ca 1384-ca 1453 Een socıaal polttieke studie van een staatsvormingsproces (Brussels 1990), H Brand, Over macht en overwicht Stedelyke elties in Leiden (1420 1510) (Leuven/Apeldoorn 1996) $111-17,2418$

${ }^{14} \mathrm{C}$ de Haan \& J Oosterman (eds ), Is Brugge Groot ${ }^{9}$ (Amsterdam 1996) 156-61
} 
council listed 38 in 1302 and 63 in 1394-96. ${ }^{15}$ The fifteenth-century censuses of the inhabitants of Gemene Neringen, a district of Ypres, a typical industrial town, show that in 1471 there were 161 different occupations for 697 heads of household. Of these 697 household heads with a registered occupation 165 , or $23 \%$, were female. They included 62 spinners and 45 wercwivven, cleaning women. In addition, there was a large number of widows who carried on the occupations of their husbands, others who worked as dressmakers, washerwomen or fruit sellers. Women's participation in predominantly low-qualified jobs was probably even greater in the districts known for drapery and fullers' work, areas where the textile industry was traditionally established. Indications of occupations are not available for these areas. Sets of data are available, however, on the composition of families in all the districts. These data reveal a large number of single people: $20 \%$ in 1412 in the district of Gemene Neringen, mentioned above, and accordingly throughout the entire town a noticeably small average number of members to a family, i.e. 3.2 in 1412, 4.3 in 1491 and 4.2 in 1506. Pirenne studied these figures and concluded '... plus l'activité industrielle est intense dans une ville du moyen âge, plus la densité des ménages y est faible'. ${ }^{16}$

In many occupational categories in towns of the southern Netherlands female labour had been established since the thirteenth century. A widow of a master craftsman carried on her late husband's business without any problem because she had been accustomed to work at his side. In at least thirteen of the 52 Ghent guilds, the daughters of masters were entitled to be trained in the craft, whenever it was highly unlikely that they would climb up the scale to become an independent journeyman or master. ${ }^{17}$ To be sure,

${ }^{15}$ I de Meyer, 'De sociale strukturen te Brugge in de 14e eeuw', in' W Blockmans et al (eds.), Studien betreffende de sociale strukturen te Brugge, Kortrijk en Gent in de $14 \mathrm{e}$ en 15 e eeuw, Standen en Landen 54 (Heule 1971) 30-2

${ }^{16} \mathrm{H}$ Prrenne, 'Les dénombrements de la population d'Ypres au XV siècle (1412-1506)', In. Id, Histotre économique de l'Occident médiéval (Bruges 1951) 468-71, 478-86 (onginally published in Vierteljahrschrift fur Sozlal- und Wirtschaftsgeschichte 1 (1903) 458-89) Some more recently published comparative materials are discussed in W Blockmans et al, 'Tussen crisis en welvaart' sociale veranderingen 1300-1500', in. W. Blockmans et al (eds ), Algemene Geschiedenis der Nederlanden 4 (Haarlem 1980) 43.

${ }^{17}$ Danneel, Weduwen en wezen, 349-82, esp 360-1, M C Howell, Women, Production, and Patriarchy in Late Medieval Cities (Chicago 1986) 70-94, her thesis, that 'women's labor-status [lowered] by closing manr of the positions that granted high labor-status to women, forcing women of Leiden's Mittelschicht to retreat from market production' has met some criticism. H. Brand, 'Personal Government or Urban Policy? The Involvement 
in the large-scale textile industry mainly lower-rated jobs were available to women, many of whom were single, as was the case in Ypres in 1412; but the phenomenon was certainly older than the rise of the literary theme of the domineering wife, and thus cannot explain its increasing popularity. On the contrary, growing unemployment and impoverishment resulted in fewer single people being counted in Ypres in the course of the fifteenth century.

While Ypres, Leuven and a number of other towns saw an increase in de-industrialization during the fifteenth century, elsewhere - Antwerp and the surrounding area, for example, and Holland - quite the reverse was happening. This process continued during the sixteenth century, especially during the second half. Shifts in migration patterns must have brought about this sort of structural change.

Socio-economic development was thus very diverse, depending on the region in question. Moreover, there is absolutely no proof that the transformations implied specifically excluded women; ${ }^{18}$ nor was it necessarily participation in labour that drove women from their homes. Indeed, the largest category, the spinners, could have carried out their work at home, on their distaffs. In short, socio-economic changes were extremely fragmented, complex and diverse, and occurred too disparately to make a general interest in a particular literary theme likely. If we cannot find a connection between the socio-economic situation in a town and the success of a particular trend there, then a reference to that context suggests more than it can prove.

Pleij refers to one specific case, concerning a Brussels regulation of 1424 , on the subject of certain female occupations. He believes that this regulation indicates that "women were being held back, especially in the areas of medicine and caregiving'. His interpretation here diverges from recent historical literature on this subject. ${ }^{19}$ This literature places the

of the Urban Top Layer in the Economy of Leiden in the Late Middle Ages', in H Diederiks et al (eds), Economic Policy in Europe since the Late Middle Ages (Leicester/New York/London 1992) 17-34, id, 'Crisis, beleid en differentiatie in de laatmiddeleeuwse Leidse lakennijverheid', in J K S Moes \& B M A de Vries (eds), Stof ut het Leidse Verleden Zeven eeuwen textielnijverheld (Utrecht 1991) 53-65.

${ }^{18} \mathrm{H}$ van der Wee (ed.), The Rise and Decline of Urban Industries in Italy and in the Low Countres (Late Middle Ages - Early Modern Times) (Louvain 1988) 307-47

${ }^{19}$ Pleıj, 'Taakverdelıng', 75 I cannot agree with the translation of buddersen as 'hostesses', in my opinion the intended meaning is women who pray at a death-bed, A Delva, Vrouwengeneeskunde in Vlaanderen tydens de late middeleeuwen (Bruges 1983) 109-13 
Brussels ordinance of 1424 precisely within the context of the professionalization of the officie van vroedvrouwschap (office of midwifery), for which after a period of training, a theoretical examination, a test of competency and an oath of office were prescribed. In the major towns of the southern Netherlands midwives who were officially recognized and/or appointed enjoyed a status comparable to that of male masters in other trades. The Antwerp city council had at least four midwives in its employ in 1544. Before the seventeenth century there was generally no question of male academics forcing women out of this profession. A somewhat belated evolution in this direction could be observed in Leiden. From 1440 to 1460 a decree enabled surgeons to exclude women from some of their activities, such as blood-letting and cupping. In 1463, however, the city magistrate appointed a midwife recruited in Antwerp. Midwifery remained a purely female business certainly until the middle of the sixteenth century. Most cities in the northern Low Countries employed a midwife to assist poor mothers and to oversee and provide advice to her female colleagues. In 1518 , the city of Delft even appointed two midwives and two apprentices. Their social status was considerable. ${ }^{20}$

A happy coincidence enables us to see this situation, which we know of from urban regulations and accounts, represented in a contemporaneous dramatic production at the regional drama festival Landjuweel held at Diest in 1541. In Van Tielebuys die een jaer te vroech gheboren is ende wert herdraghen ('Van Tielebuys who was born one year early and was carried back'), dame Pertmans, 'our town's midwife and mistress of the principles,' hears from her servant (maerte) the remark that she has been 'well schooled by the women' but that in her drunkenness she should still not make any serious professional errors. ${ }^{21}$ While official documents show irrefutably that, at least until the middle of the sixteenth century, midwives formed an exceptionally qualified occupational category, this play in no way disputes that. It is precisely the drunkenness of the mistress that gives the maerte the chance to reverse their roles, but in the nature of things it is just a temporary lesson. It only serves to endorse the hierarchy between the learned mistress and her assistant. People may laugh at the midwife who briefly forgot her role, but there is absolutely no question of a 'literary witch hunt against illegally functioning midwives'.

${ }^{20}$ A. Netiv, 'Leidse stadvroedvrouwen', in: J. Marsilje et al. (eds.), Uit Leidse Bron Geleverd (Leiden 1989) 169-72; D.E.H. de Boer, "Het Leids medisch "netwerk" omstreeks 1465', Leids Jaarboekje 76 (1984) 70-4.

${ }^{21}$ M. de Jong, Drie zestiende-eeuwse esbatementen (Amsterdam 1934) 38. 


\section{Representation}

Pictorial representations also play a part in Pleij's argumentation. On one hand, he rightly points to the numerous woodcuts where incongruous love is ridiculed. On the other, he has to conclude that other sources are tapped here than in dramatic literature, i.e. the feminine wiles of classical heroines. Further research should clarify the matter: it would then be essential to bear in mind the frequency of the themes and how representative they are. It is not difficult to select prints showing scolding women pursuing their husbands, but how many images of man and woman in harmony cannot be found to counterbalance that? Thousands of miniatures in books of hours from the late fifteenth and early sixteenth century show men and women working together harmoniously in all sorts of occupations. The same is true of other media, such as tapestries (the grape harvest, for example, in the Cluny Museum). One objection could be that these products created an idealistic picture because, partly on account of their cost, they were intended for the highest social classes. This may well be, but do we then find only scolding women in the more widely available products? What is needed here is a statistical analysis which would naturally involve all the achievements of the source-criticism (originality or re-use of woodcuts, relation to the text). ${ }^{22}$ There were, after all, many changes taking place simultaneously round about 1500: realism gains the upper hand in (theatrical) performances, religious functions and subjects lose ground, ancient models, including the blatant nude, are copied more and more, and the spread of printing makes reproduction possible on a wide scale. Among such a complexity of factors it is methodologically invalid to reduce explanations to a selection that cannot be tested for representativeness.

\section{Crimes within Marriage}

Judicial archives enable us to look into the incidence of undesirable behaviour in real life. Court registers contain often very explicit descriptions of the situations brought before the court, which are best compared to literary scenes. The fact that a complaint must indeed have been brought by a victim or witnesses so that the authorities would intervene in the private area of marriage, expresses more interpretations than only those of the people directly concerned and of the court. Various researchers have in

\footnotetext{
${ }^{22}$ See the article by Hanneke de Bruin in this volume.
} 
recent years published their findings on the administration of criminal justice in the towns of the northern Netherlands, and have thrown light on the value of these sources for the real system of norms and values. ${ }^{23}$ To this series can be added research into cases concerning marital affairs coming before the Leiden sheriffs between 1442 and $1570 .{ }^{24}$

In the search for cases of marital discord what strikes us first is that, during the course of an entire century, the Leiden sheriffs and aldermen passed judgement in only seven such cases. Of course, there will have been far more going on that never got as far as the Town Hall. The sheriff had the power to impose fines for minor infractions. In the few accounts preserved for Leiden at the end of the fifteenth century, the first rubric enumerates cases of the use or the threat of violence, labelled messtreckinghe. In the year 1486-87, three women were fined as against 105 men. ${ }^{25}$ Obviously it was not women who constituted the most serious threat to the men's security.

All the known lawsuits were heard either partly or entirely in public and had thus become the domain of town government. In this way we learn something about what happened and how it actually occurred. In one case the sheriff and aldermen did not feel justified in meting out punishment because the offences had taken place in the privacy of the home. Nevertheless, because it was a serious matter they were concerned and through reconciliation proceedings created the possibility of prosecuting in the future if the offence was repeated. In 1448 Reyner Jacopsz. had, at an ungodly hour, tied up his wife, Hillewair, naked to beat and maltreat her. There were no witnesses, but people did report on the scandalous behaviour of both husband and wife. There was insufficient reason for the sheriff and aldermen to resort to punishment, but enough to enjoin Hillewair, in a deed of reconciliation, to obey her husband insofar as he was decent, reasonable and seemly, and to forbid him to beat and maltreat her. Both had to promise that they would not cause harm to each other. ${ }^{26}$ In fact, in the material studied there was no case where a woman was prosecuted for disobeying her husband.

\footnotetext{
${ }^{23}$ D.A. Berents, Het werk van de vos (Zutphen 1985); De Meyer, Min en onmin; J.E.A. Boomgaard, Misdaad en straf in Amsterdam. Een onderzoek naar de strafrechtspleging van de Amsterdamse schepenbank 1490-1552 (Zwolle 1992).

24 The data for this was originally compiled in a master's dissertation by Tess Neijzen, History department, Leiden University, 1992.

${ }^{25}$ Gemeente-archief Leiden (GAL), Secretarie 1001.

${ }^{26}$ Gemeente-archief Leiden, Oud Rechterlijk Archief (henceforth: ORA), inv. no. 2, f. 132v.
} 
Only seven incidents of marital violence appeared in the court registers in Leiden. Of these, just one corresponded to the literary theme; the others all concerned violence on the part of the husband. In 1483 at the request of her husband, Jacop Dircxz, the affairs of Clair Pottebachster were put into receivership because of her many debts. So insulted did she feel at this that she decided to take revenge. Together with Jacopeyn Pietersdr., early in the morning when the neighbours were at church, she contrived to drag Jacop from his bed, set him in a chair, address him in humiliating language, throw him to the ground and thereupon assault him. Jacopeyn hit him so hard in his manhood that he cried out in pain, but he was powerless against the two women as he was old and weak. Hearing his cries, neighbours and passersby came in to see what was going on. ${ }^{27}$ Both women were sentenced to make a pilgrimage to Aachen as punishment; because Jacopeyn's offence was more serious she also had to appear before the court carrying a wax candle weighing one pound and ask forgiveness: afterwards she had to offer the candle to the Holy Cross.

All of the six men convicted had acted violently. In the charge against Oerlof Reyersz. it appeared that violence had been directed at another man, Willem Jansz., whose windows he had broken and whom he had threatened with a knife; other circumstances were taken into consideration, viz. that he behaved badly towards his wife, was regularly drunk and gambled his possessions away. He was sent on a pilgrimage to Rome. ${ }^{28}$

Repeated drunkenness was a charge brought against four of the six men. Two of them apparently felt an irresistible urge to take their clothes off in the street. In all these cases the court imposed a sentence that physically separated husbands and wives: for three of them a long pilgrimage, and in one case a prison sentence of six weeks on bread and water after having first walked through the town with the town drum, the stedeton, round his torso. $^{29}$

The heaviest sentence was given to Dirck Cornelisz. de Pruiche who returned home drunk one night in 1540 in his linen shirt, undressed further in the street and pushed his way into his house so noisily that his heavily pregnant wife took flight. A few days later she was already in labour when Dirck once again came home drunk, forced the women present out of the house and got into bed with his wife, despite her entreaties not to. $\mathrm{He}$

\footnotetext{
${ }^{27}$ GAL ORA 4 C, f. 84v.

${ }^{28}$ GAL ORA 4 H, ff. 155-156.

${ }^{29}$ GAL ORA 4 C, f 113 r; G, f. 138r; H, ff. 32-33.
} 
claimed to have enough knowledge to make the presence of a midwife unnecessary. Because he thus threatened the life of mother and child he was sent on a pilgrimage to Santiago de Compostella and further banished for three years. ${ }^{30}$

In addition to these offences within marriage, between 1442 and 1540 the sheriffs and aldermen of Leiden also punished eight men who only failed to assault their wives because the women managed to reach a safe shelter just in time. A similar number of women had left their drunken and wanton husbands and found a home with a parent, brother or even with Maritgen tvroewijff ('Mary the midwife') (1537). In all these cases the court approved the separation and because of the men's violent behaviour in public places, damage to windows and other parts of houses, as well as provocation and bodily harm, it sentenced them to pilgrimages to Rome, Santiago and Einsiedeln, adding a prison sentence and a humiliating punishment. ${ }^{31}$ Even more noticeable here than in the cases of attacks inside a marriage is that the women are always the endangered party who, even when they have found refuge with honourable people and close family, are still not safe from their husbands.

When one remembers that the court consisted exclusively of men it is particularly remarkable to record that it was the court that systematically took women into protection, sent aggressive men away, or imprisoned and humliated them. Without doubt the fifteen cases referred to were merely the tip of the proverbial iceberg of marital problems in Leiden. Nevertheless, these sources from legal practice can in no way lead us to suppose that the town government would have used this means to have supported any form of oppression of women. On the contrary, as Godelieve de Meyer concluded, both the making of a marriage and the ending of it (through divorce or separation) were faurly informal affairs which the secular authorities adopted pretty quickly. The one elderly man who was so rudely attacked by the friend of his extravagant wife can in no way offset the numerous broken windows and challenges, threats, blows and wounds caused by fourteen men.

\footnotetext{
${ }^{30}$ GAL ORA 4 H, f 151.

${ }^{31}$ GAL ORA 2, if. $32 \mathrm{v}, 39,42,43,84,185,4 \mathrm{G}$, ff $21-22,4 \mathrm{H}$, ff $2 \mathrm{v}, 23 \mathrm{v}-24 \mathrm{v}, 138$
} 


\section{In Search of an Explanation}

Let us return to Herman Pleij's intriguing question: why was the theme of the domineering wife so popular in literature? By now we know that in general the position of the woman could not have been seen as increasingly competitive. For centuries women had worked side by side with their husbands and other men and were valued for their professional qualities. There can be no question of a drastic and general change in family relationships about 1500 . If we look at the administration of law we see that it is the men themselves who were the greatest instigators of mischief and commotion. It is remarkable that certain frequent patterns of male behaviour, which were often the cause of all their difficulties, were just not exposed in literature: alcoholism and violence. Our example of drunkenness found in a comedy involved a midwife.

If we strictly apply the ratio of 1:14 in the lawsuits looked at to the success of the literary theme of the domineering wife, then it is clear that real-life relationships have been reversed in fiction. We dare not seek an explanation for this in socio-economic circumstances because these vary so much according to place or region. To get any further in understanding the complicated relationship between fiction and reality we would also have to consider the need to suppress the real problems of violence and alcoholism. Nobody could have seen the domineering wives as a real problem, otherwise they would never have made amusing theatre. 